\title{
MODEL OPTIMISASI DENGAN SASARAN BERAGAM UNTUK PENGELOLAAN PERIKANAN UDANG DI LAUT ARAFURA
}

\author{
Purwanto \\ Peneliti pada Pusat Penelitian Pengelolaan Perikanan dan Konservasi Sumber Daya Ikan, Ancol-Jakarta \\ Teregistrasi I tanggal: 24 Januari 2011; Diterima setelah perbaikan tanggal: 21 April 2011; \\ Disetujui terbit tanggal: 29 April 2011
}

\begin{abstract}
ABSTRAK
Kriteria pengelolaan perikanan dalam kerangka pembangunan nasional, yaitu pro-growth, pro-poor, pro-job, dan pro-environment, mengarahkan pengelolaan perikanan udang di Laut Arafura untuk mencapai kelangsungan produktivitas stok udang, mengoptimumkan produksi dan total keuntungan perikanan, serta meningkatkan keuntungan pelaku usaha dan peluang kerja di kapal perikanan. Sementara itu, visi dan misi Kementerian Kelautan dan Perikanan memberikan prioritas yang lebih tinggi kepada optimisasi produksi dan total keuntungan perikanan. Tujuan-tujuan pengelolaan perikanan tersebut saling bertentangan sehingga tidak dapat dicapai secara bersamaan. Oleh karena itu perlu ditentukan tingkat kompromi optimal di antara tujuan-tujuan tersebut dan sasarannya. Tulisan ini menyajikan model pemrograman matematika untuk optimisasi dengan tujuan beragam yang mengakomodasikan empat sasaran pengelolaan perikanan serta menggunakannya untuk mengestimasi tingkat kompromi optimal dari empat sasaran tersebut dan jumlah optimal kapal penangkap udang. Hasil analisis dengan memberikan bobot prioritas yang sama terhadap empat tujuan pengelolaan perikanan dalam kerangka pembangunan nasional menunjukkan bahwa tingkat kompromi optimal dicapai dengan pengendalian upaya penangkapan pada tingkat yang setara dengan 511 kapal pukat udang berukuran 130 GT. Tingkat kompromi optimal yang sama dihasilkan dari analisis dengan memberikan bobot prioritas yang lebih tinggi terhadap dua tujuan pengelolaan perikanan untuk mendukung upaya pencapaian visi dan misi Kementerian Kelautan dan Perikanan. Hal ini mengindikasikan bahwa strategi pengelolaan perikanan guna mendukung pencapaian visi dan misi Kementerian Kelautan dan Perikanan tidak berbeda dari strategi pengelolaan perikanan dalam kerangka pembangunan nasional.
\end{abstract}

KATAKUNCI: bio-ekonomi, pemrograman dengan sasaran beragam, perikanan udang, Laut Arafura

\section{ABSTRACT: The optimisation model of multiple goals for the management} of shrimp fishery in the Arafura Sea. By: Purwanto

The criteria of fisheries management undertaken in a framework of national development, particularly pro-growth, pro-poor, pro-job, and pro-environment, guide the management of shrimp fishery in the Arafura Sea to achieving sustainable shrimp stock productivity, optimising shrimp production and total fishery profit, and increasing average fisher profit and job opportunity as vessel crews. Meanwhile, the vision and the mission of the Ministry of Marine Affairs and Fisheries provided higher priorities to optimising shrimp production and total profit of fishery. However, those objectives were conflicting that couldnot be achieved simultaneously. Therefore, it is necessary to seek an optimal compromise amongst several conflicting objectives or to achieve satisficing levels of goals. This paper presents a mathematical programming model

Korespondensi penulis:

Jl. Pasir Putih I, Ancol Timur-Jakarta 14430, Telp. (021) 64711940, Fax. (021) 6402640, E-mail:

rccfoffice@indo.net.id 
accommodating four goals of fishery management, and the utilisation of this for estimating the optimal compromise solution to the goals and the optimal number of fishing vessels. The result of analysis shows that the optimal compromise levels for the four conflicting objectives of fishery management supporting the national development could be achieved by controlling fishing effort at the level equal to 511 shrimp trawlers of 130 GT. The same optimal compromise levels resulted from the analysis providing higher priority to the objectives to achieve the vision and the mission of the Ministry of Marine Affairs and Fisheries. This indicates that the fishery management strategy to achieve the vision and the mission of the Ministry of Marine Affairs and Fisheries was not different from the strategy to support the national development.

KEYWORDS: bio-economic, multiple goal programming, shrimp fishery, Arafura Sea

\section{PENDAHULUAN}

Laut Arafura merupakan daerah utama untuk penangkapan udang bagi armada perikanan Indonesia. Berdasarkan atas data dari Departemen Kelautan dan Perikanan (2007), stok udang di perairan tersebut diperkirakan sekitar $45 \%$ dari seluruh stok udang di Indonesia. Namun demikian, stok udang tersebut dilaporkan telah dimanfaatkan berlebih (Widodo et al., 2001; Departemen Kelautan dan Perikanan, 2007), sebagai akibat jumlah kapal penangkap yang diizinkan beroperasi melebihi tingkat optimumnya dan intensitas penangkapan secara ilegal relatif tinggi (Purwanto, 2010). Konsekuensi dari hal tersebut adalah kelimpahan stok dan kemampuan produksinya lebih rendah dari tingkat optimumnya (Naamin, 1984; Badrudin et al., 2002; Purwanto, 2010) dan keuntungan ekonomi yang diperoleh pelaku usaha lebih rendah dibanding tingkat optimum, bahkan sebagian pelaku usaha mengalami kerugian (Purwanto, 2011). Setelah dilakukan penataan perizinan, termasuk pula perbaikan pengendalian perikanan lainnya, serta peningkatan pengawasan perikanan dan penegakan hukum, intensitas penangkapan udang menurun sampai mendekati tingkat optimum (Purwanto, 2010).
Pada dasarnya bila stok udang dimanfaatkan secara bertanggungjawab, sehingga sumber daya tersebut lestari, akan menjamin kelangsungan usaha penangkapan. Hal ini akan menjamin kelestarian industri hulu dan hilirnya. Agar stok udang lestari serta dapat menghasilkan manfaat secara optimum dan berkelanjutan, pemerintah atau otoritas lain perlu melaksanakan pengelolaan terhadap perikanan yang memanfaatkan sumber daya tersebut (Pasal 1 dan 6 Undang-Undang Nomor 31 Tahun 2004 tentang perikanan). Pengelolaan perikanan tersebut diarahkan untuk mencapai kelangsungan produktivitas sumber daya hayati perairan dan tujuan yang telah disepakati (Pasal 1 UndangUndang Nomor 31 Tahun 2004). Pengelolaan perikanan udang secara benar yang dilaksanakan oleh pemerintah atau otoritas lain, dengan tujuan agar sumber daya lestari dan dapat dipergunakan untuk sebesar-besar kemakmuran rakyat, pada dasarnya merupakan pelaksanaan Pasal 33 Undang-Undang Dasar Negara Republik Indonesia Tahun 1945 (Undang-Undang Dasar 1945).

Sumber daya udang di Laut Arafura merupakan salah satu modal dasar dalam pembangunan nasional, sebagaimana tercantum dalam rencana pembangunan jangka panjang nasional (Undang-Undang Nomor 17 Tahun 2007). Pengelolaan 
perikanan secara benar diharapkan akan memberikan dukungan optimum terhadap pembangunan nasional dengan kontribusi positif dalam kaitan dengan pertumbuhan ekonomi (pro-growth), pendapatan per kapita (pro-poor), kesempatan kerja (pro-job), dan kelestarian sumber daya alam dan lingkungannya (pro-environment). Oleh karena itu, strategi pengelolaan perikanan perlu disusun dan diputuskan dengan mempertimbangkan empat kriteria tersebut. Pengambilan keputusan dengan kriteria beragam tersebut memiliki beberapa tujuan (objectives), mencakup peningkatan pertumbuhan ekonomi, peningkatan pendapatan per kapita dan perluasan kesempatan kerja, dengan tetap mempertahankan kelestarian sumber daya ikan dan lingkungan, untuk mencapai sejumlah sasaran (goals). Pengambilan keputusan tersebut dilakukan untuk mencari suatu kompromi optimal di antara beberapa tujuan, yang seringkali bertentangan, atau untuk mencoba mencapai sasaran pada tingkat yang memuaskan (Romero \& Rechman, 1989). Optimisasi untuk pengelolaan perikanan dengan beragam tujuan atau sasaran telah dilakukan antara lain oleh Drynan \& Sandiford (1985); Sandiford (1986); Mardle et al. (2000); Kjaersgaard \& Andersen (2003) menggunakan goal programming, serta Purwanto (2003; 2011) menggunakan compromise programming.

Drynan \& Sandiford (1985); Sandiford (1986) melakukan analisis untuk pengelolaan perikanan pantai di Skotlandia. Drynan \& Sandiford (1985) memberikan ilustrasi sejumlah pemrograman sasaran yang memasukkan pula alternatif tujuan ekonomi dari pengelolaan perikanan. Sementara itu, Sandiford (1986) menggunakan pemrograman sasaran untuk menentukan alokasi optimal sumber daya ikan bagi perikanan pantai. Mardle et al. (2000) menyusun dan menggunakan model pemrograman sasaran beragam dengan beberapa skenario untuk analisis dan penyusunan rencana pengelolaan perikanan serta alokasi perikanan di Laut Utara bagi negara-negara anggota Uni Eropa. Kjaersgaard \& Andersen (2003) juga menyusun dan menggunakan model pemrograman sasaran beragam untuk perikanan di Laut Utara, namun dalam kaitan dengan optimisasi pengelolaan perikanan industri di Denmark. Optimisasi dengan tujuan beragam untuk kasus pengelolaan perikanan di Indonesia dilakukan oleh Purwanto (2003; 2011), masing-masing untuk perikanan multi species dan multi gear di Laut Jawa serta perikanan udang di Laut Arafura. Dua kasus ini dianalisis untuk mengestimasikan tingkat optimal yang merupakan kompromi dari dua tujuan. Sementara itu, terdapat empat kriteria yang perlu diakomodasikan dalam perumusan strategi pengelolaan perikanan dalam kerangka pembangunan nasional.

Tulisan ini menyajikan model pemrograman matematika untuk optimisasi dengan tujuan beragam yang mengakomodasikan empat sasaran pengelolaan perikanan udang di Laut Arafura. Model tersebut selanjutnya digunakan untuk mengestimasi tingkat kompromi optimal dari empat sasaran tersebut dan jumlah optimal kapal penangkap udang.

\section{PERIKANAN UDANG LAUT ARAFURA}

\section{Biomassa Udang, Produktivitas Kapal, dan Produksi Udang}

Kegiatan penangkapan udang secara komersial di Laut Arafura mulai berkembang sejak tahun 1970-an setelah ditemukan stok udang yang melimpah dan diperkenalkan pukat udang untuk pemanfaatannya (Bailey et al., 1987). Intensitas pemanfaatan stok udang di Laut 
Arafura semakin meningkat dengan dioperasikannya pukat ikan pada kawasan yang relatif sama mulai pertengahan tahun 1980-an. Peningkatan kegiatan penangkapan udang tersebut telah menyebabkan penyusutan biomassa udang di perairan tersebut, sehingga produktivitas kapal penangkap udang juga menurun.

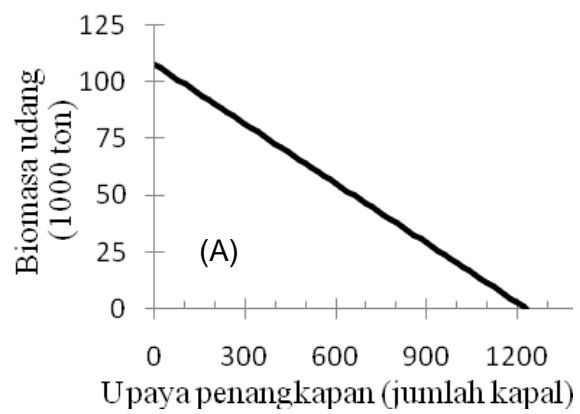

Perkembangan yang pesat dan berlanjut dari intensitas penangkapan oleh armada perikanan pukat udang dan pukat ikan sampai tahun 2000 telah berdampak pada penurunan yang tajam dari kelimpahan biomassa udang dan produktivitas kapal penangkapnya (Gambar 1).

Gambar 1. (A) Estimasi biomassa udang dan (B) estimasi volume udang hasil tangkapan per satuan upaya penangkapan, pada perikanan udang di Laut Arafura pada berbagai tingkat upaya penangkapan.

Figure 1. (A) The estimated shrimp biomass and (B) estimated shrimp catch per unit effort, in the Arafura shrimp fishery at different level of fishing effort. Sumber/Sources: Purwanto (2010)

Pada stok udang yang belum pernah dimanfaatkan (virgin stock), berkurangnya biomassa udang sebagai akibat dari peningkatan kegiatan penangkapan diikuti oleh meningkatnya laju pertumbuhan biomassa tersebut, sehingga produksi udang juga meningkat. Pada saat pertumbuhan biomassa mencapai laju maksimum, dihasilkan produksi lestari maksimum (maximum sustainable yield). Setelah dicapai laju pertumbuhan biomassa maksimum, peningkatan berlanjut pada upaya penangkapan menyebabkan menyusutnya biomassa udang dan laju pertumbuhannya, sehingga produksi udang juga menyusut (Gambar 2). Biomassa udang dengan laju pertumbuhan maksimum di Laut Arafura adalah 54.000 ton, sedangkan maximum sustainable yield dari stok udang tersebut adalah 46.000 ton per tahun yang dipanen dengan upaya penangkapan $\left(\mathrm{E}_{\mathrm{MSY}}\right)$ sekitar 616 unit kapal pukat udang berukuran 130 GT (Purwanto, 2010). 


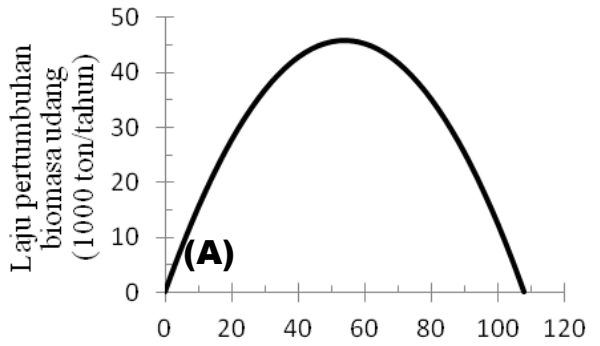

Biomasa udang (1000 ton)

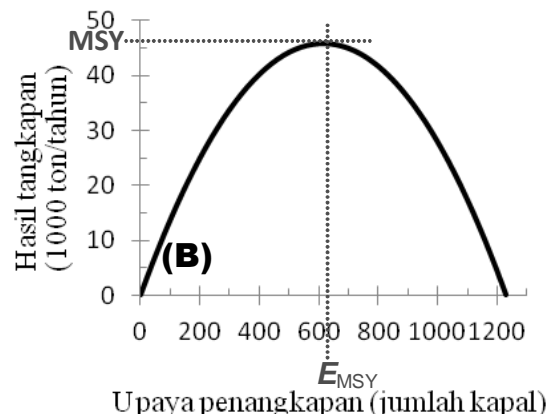

Upaya penangkapan (jumlah kapal)

Gambar 2. Hubungan antara (A) laju pertumbuhan biomassa dan biomassa udang serta (B) volume total udang hasil tangkapan dan tingkat upaya penangkapan pada perikanan udang di Laut Arafura.

Figure 2. The relationships between $(A)$ biomass growth rate and biomass of shrimps and $(B)$ shrimp catch and fishing effort in the Arafura shrimp fishery.

Sumber/Sources: Purwanto (2010)

\section{Usaha Perikanan Udang}

Penangkapan udang di Laut Arafura pada dasarnya adalah kegiatan ekonomi yang dilakukan untuk memperoleh keuntungan. Perkembangan usaha tersebut sangat dipengaruhi oleh kekuatan ekonomi yang menentukan besarnya keuntungan, khususnya biaya penangkapan dan harga udang. Adanya keuntungan pada usaha penangkapan udang telah mendorong pelaku usaha untuk mengembangkan armada penangkapannya, guna meningkatkan kapasitas usahanya. Hal ini menyebabkan peningkatan upaya penangkapan pada perikanan udang di Laut Arafura. Namun, keterbatasan daya dukung stok udang pada perairan tersebut menjadi kendala utama pengembangan usaha tersebut. Produktivitas dan keuntungan pelaku usaha per unit kapal menurun dengan semakin tingginya upaya penangkapan udang. Keuntungan usaha tidak lagi diperoleh, bahkan merugi, bila upaya penangkapan terus meningkat tanpa kendali. Di lain pihak, semakin tinggi upaya penangkapan semakin banyak nelayan yang bekerja di kapal penangkap (Gambar $3(A))$.
Sementara itu bila ditinjau dari total keuntungan perikanan udang, total keuntungan meningkat dengan peningkatan upaya penangkapan pada saat stok udang pada tingkat pemanfaatan rendah. Setelah mencapai total keuntungan maksimum, peningkatan lebih lanjut pada upaya penangkapan justru menyebabkan turunnya total keuntungan perikanan (Gambar 3(B)). Pada saat biaya penangkapan dan harga udang masing-masing US\$304.000 per kapal per tahun dan US\$6.0 per kilogram, total keuntungan maksimum yang dapat dicapai dari pemanfaatan stok udang di Laut Arafura adalah sekitar US\$120 juta per tahun (Purwanto, 2011). Produksi udang yang dihasilkan pada saat dicapai tingkat keuntungan maksimum tersebut, yaitu produksi yang secara ekonomis maksimum (maximum economic yield), sekitar 41.000 ton/tahun, yang dipanen dengan upaya penangkapan $\left(\mathrm{E}_{\mathrm{MEY}}\right)$ sekitar $406 \mathrm{kapal}$ penangkap udang berukuran $130 \mathrm{GT}$. Hal ini menunjukkan bahwa upaya penangkapan yang dibutuhkan untuk menghasilkan keuntungan optimum adalah lebih rendah dibandingkan upaya penangkapan untuk menghasilkan maximum sustainable yield. 

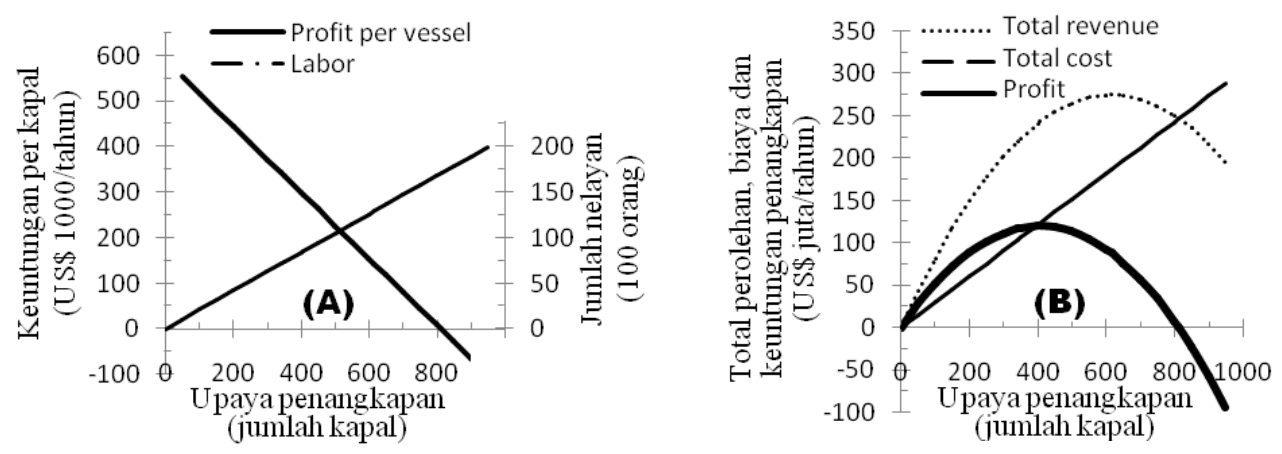

Gambar 3. (A) Estimasi tingkat keuntungan per kapal dan jumlah nelayan yang bekerja di kapal serta (B) estimasi total perolehan, total biaya, dan total keuntungan penangkapan udang di Laut Arafura pada berbagai upaya penangkapan ikan.

Figure 3. (A) The estimated profit per unit vessel and the number of fishers working on board and $(B)$ the estimated total revenue, total cost and profit generated in the Arafura shrimp fishery at different level of fishing effort. Sumber/Sources: Purwanto (2011)

\section{Pengendalian Penangkapan Udang}

Bila pelaku usaha perikanan dapat memahami fenomena perikanan tangkap dan bersedia menghentikan peningkatan upaya penangkapannya saat dicapai tingkat keuntungan optimum, maka sumber daya ikan akan lestari dan kelangsungan usahanya akan terjamin. Namun, stok udang di Laut Arafura merupakan sumber daya milik umum atau milik bersama (common property), tidak seorangpun memiliki hak khusus untuk memanfaatkan sendiri ataupun melarang orang lain ikut memanfaatkan sumber daya alam tersebut. Akibatnya, setiap pelaku usaha berlomba meningkatkan upaya penangkapannya dengan harapan mendapatkan hasil tangkapan yang lebih banyak. Namun, kondisi yang dihadapi adalah terjadinya penurunan hasil tangkapan dan keuntungan yang diperoleh masing-masing unit kapal, serta peningkatan ancaman terhadap kelestarian stok udang, sebagai dampak peningkatan upaya penangkapan tersebut. Oleh karena itu, campur tangan atau intervensi Pemerintah dalam kerangka pengelolaan perikanan diperlukan untuk mengendalikan kegiatan penangkapan udang.

Kriteria dalam pengelolaan perikanan dalam kerangka pembangunan nasional adalah pro-growth, pro-poor, pro-job, dan proenvironment. Oleh karena itu, pengelolaan perikanan udang di Laut Arafura perlu diarahkan untuk mengoptimumkan produksi udang dalam rangka mendorong pertumbuhan ekonomi (tujuan I), mengoptimumkan total keuntungan dari perikanan udang (tujuan II), meningkatkan keuntungan per unit kapal yang diperoleh pelaku usaha penangkapan udang (tujuan III), dan meningkatkan peluang kerja sebagai awak kapal penangkap udang (tujuan IV), dengan tetap mempertahankan kelestarian stok udang. Walaupun upaya pengelolaan perikanan diarahkan untuk mencapai semua tujuan pengelolaan, prioritas dapat ditetapkan dalam mencapai tujuan tersebut. Pertimbangan utama dalam penetapan prioritas tersebut adalah visi dan misi Kementerian Kelautan dan Perikanan. 
Visi Kementerian Kelautan dan Perikanan dalam pembangunan kelautan dan perikanan untuk periode tahun 2010-2014 yaitu Indonesia penghasil produk kelautan dan perikanan terbesar tahun 2015. Untuk merealisasikan visi tersebut, berbagai upaya dilakukan untuk peningkatan produksi kelautan dan perikanan. Namun, peningkatan produksi perikanan tangkap bukan tanpa batas, stok udang memiliki keterbatasan dalam mendukung kegiatan produksi perikanan udang (Gambar 2). Setelah produksi mencapai tingkat maximum sustainable yield, peningkatan kegiatan penangkapan tidak akan menghasilkan peningkatan produksi udang secara lestari. Mempertimbangkan hal tersebut, maka visi Kementerian Kelautan dan Perikanan tersebut dalam kaitan dengan pengelolaan perikanan udang dapat diterjemahkan menjadi optimisasi produksi udang, yang merupakan tujuan-I dalam pengelolaan perikanan udang, agar Indonesia menjadi penghasil produk kelautan dan perikanan terbesar tahun 2015.

Sementara itu, misi Kementerian Kelautan dan Perikanan adalah mensejahterakan masyarakat kelautan dan perikanan. Sesuai dengan Pasal 33 (3) Undang-Undang Dasar 1945, kesejahteraan masyarakat tersebut tidak dapat diartikan sebagai kesejahteraan orang per orang, melainkan kesejahteraan semua orang dalam komunitas kelautan dan perikanan. Pada kasus perikanan udang, hal tersebut dapat diartikan sebagai kesejahteraan masyarakat perikanan udang. Oleh karena itu, misi Kementerian Kelautan dan Perikanan tersebut dalam kaitan dengan pembangunan dan pengelolaan perikanan udang dapat diartikan menjadi mensejahterakan masyarakat perikanan udang. Dengan menggunakan pendapatan sebagai salah satu indikator kesejahteraan dan pertimbangan keterbatasan daya dukung stok udang, maka misi Kementerian Kelautan dan Perikanan tersebut dapat diterjemahkan menjadi optimisasi pendapatan neto atau total keuntungan ekonomi perikanan udang, yang merupakan tujuan II dalam pengelolaan perikanan udang, untuk mensejahterakan masyarakat kelautan dan perikanan. Dengan demikian, tujuan pengelolaan perikanan yang memperoleh prioritas yang lebih tinggi adalah tujuan I dan II.

Beragam tujuan pengelolaan perikanan udang tersebut dapat dicapai dengan pengendalian kegiatan penangkapan. Pada saat ini pengendalian penangkapan udang dilakukan terutama terhadap input penangkapan untuk setiap stok udang pada masing-masing daerah penangkapan. Input penangkapan menggunakan ukuran unit upaya penangkapan yang diestimasi dengan mempertimbangkan jumlah dan ukuran kapal, alat penangkap, dan alat bantu penangkapan.

\section{MODEL MATEMATIKA OPTIMISASI}

Masalah pengambilan keputusan pengelolaan perikanan dengan empat tujuan (tujuan I-IV) dapat dituliskan dalam rumusan matematika berikut ini, dengan upaya penangkapan sebagai variabel keputusan. Model matematika tersebut adalah model bioekonomi yang diperkenalkan oleh Gordon (1954) dengan menggunakan model produksi dari Schaefer $(1954 ; 1957)$.

Maksimumkan: $Y=U . E$

Maksimumkan: R=h.U.E-c.E

Maksimumkan: $P=$ h.U-c

Maksimumkan: $K=k . E$

Dengan syarat:

$U=a_{1}-a_{2} \cdot E$
$B_{m} \leq b_{1}-b_{2} \cdot E$
$E \geq 0$

di mana:

$\begin{aligned} Y= & \text { produksi udang } \\ U= & \text { volume udang hasil tangkapan per } \\ & \text { unit kapal }\end{aligned}$ 


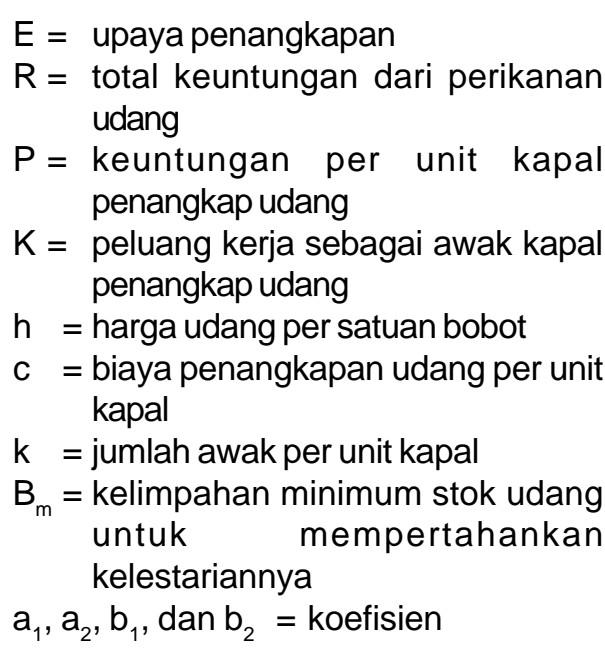

Pada pengelolaan perikanan udang di Laut Arafura, sasaran ideal untuk tujuan I adalah maximum sustainable yield yang dicapai dengan upaya penangkapan $\mathrm{E}_{\mathrm{MSY}}$, sedangkan untuk tujuan II adalah total keuntungan optimum yang dicapai dengan upaya penangkapan $\mathrm{E}_{\mathrm{MEY}}$ (Gambar 2B dan 3B). Tujuan III dicapai dengan memperkecil upaya penangkapan, namun pengurangan upaya penangkapan lebih rendah dari $\mathrm{E}_{\mathrm{MEY}}$ akan menghasilkan total keuntungan yang lebih kecil dibandingkan tingkat optimumnya, walaupun keuntungan per kapal tetap meningkat (Gambar 3). Sebaliknya, tujuan IV dicapai dengan memperbesar upaya penangkapan, namun peningkatan upaya penangkapan melebihi $\mathrm{E}_{\mathrm{MSY}}$ menghasilkan produksi udang yang lebih rendah dibandingkan maximum sustainable yield, walaupun peluang kerja di kapal penangkap udang tetap meningkat (Gambar 2B dan 3A). Sementara itu, agar stok udang setidaknya pada tingkat kelimpahan dengan laju pertumbuhan biomassa maksimum, sehingga menghasilkan produksi lestari maksimum, upaya penangkapan perlu dikendalikan paling tinggi pada tingkat $\mathrm{E}_{\mathrm{MSY}}$ (Gambar $1 \mathrm{~A}$ dan 2).
Hal-hal tersebut menunjukkan bahwa lima tujuan pengelolaan perikanan tersebut saling bertentangan sehingga tidak dapat dicapai secara bersamaan. Oleh karena itu perlu ditentukan tingkat kompromi optimal di antara beberapa tujuan yang saling bertentangan dan sasaran pada tingkat yang memuaskan. Analisis untuk menentukan tingkat kompromi optimal dilakukan dengan pemrograman matematika dengan sasaran beragam (multiple goal programming). Optimisasi dengan multiple goal programming ditujukan untuk meminimumkan deviasi relatif terhadap sasaran pengelolaan perikanan udang di Laut Arafura.

Pada tahun-tahun terakhir ini, maximum sustainable yield tidak lagi digunakan sebagai titik acuan yang menjadi sasaran (target reference point) pengelolaan perikanan melainkan sebagai titik acuan yang menjadi batas (limit reference point) dalam pengelolaan guna memperkecil resiko kegagalan pelestarian sumber daya ikan (termasuk udang) (Food and Agriculture Organization, 1997; Mace, 2001; Quinn \& Collie, 2005). Oleh karena itu, titik acuan yang menjadi sasaran adalah pada tingkat yang lebih rendah daripada maximum sustainable yield. Maximum economic yield adalah salah satu alternatif titik acuan. Pengendalian perikanan dengan sasaran maximum economic yield akan mengoptimumkan keuntungan usaha penangkapan dan lebih menjamin keberhasilan pelestarian stok udang, namun menimbulkan konsekuensi berkurangnya peluang kerja pada bidang perikanan.

Pada pemrograman matematika dengan sasaran beragam yang disajikan pada tulisan ini, pencapaian sasaran dilakukan dengan pengendalian upaya penangkapan. Nilai maksimal (ideal) dan nilai minimal (anti ideal) sasaran-sasaran pengelolaan perikanan udang yang digunakan dalam 
analisis ini menggunakan titik acuan $\mathrm{E}_{\mathrm{MEY}}$ dan $E_{M S Y}$. Pemberian prioritas yang berbeda terhadap masing-masing tujuan pengelolaan dilakukan dengan memberikannya pembobotan dengan nilai berbeda. Berikut ini adalah rumusan matematika dari masalah optimisasi tersebut untuk dipecahkan dengan multiple goal programming.

\section{Fungsi Tujuan}

Minimumkan: $\mathrm{R}=\mathrm{w}_{1} \cdot \mathrm{r}_{1}+\mathrm{w}_{2} \cdot \mathrm{r}_{2}+\mathrm{w}_{3} \cdot \mathrm{r}_{3}+\mathrm{w}_{4} \cdot \mathrm{r}_{4}(8$

\section{Fungsi Kendala}

Deviasi relatif terhadap sasaran:

$r_{1}=n_{1} /\left(G_{1}-L_{1}\right)$

$\mathrm{r}_{2}=\mathrm{n}_{2} /\left(\mathrm{G}_{2}-\mathrm{L}_{2}\right)$

$\mathrm{r}_{3}=\mathrm{n}_{3} /\left(\mathrm{G}_{3}-\mathrm{L}_{3}\right)$

$\mathrm{r}_{4}=\mathrm{n}_{4} /\left(\mathrm{G}_{4}-\mathrm{L}_{4}\right)$

Sasaran produksi udang:

$\mathrm{G}_{1}=\mathrm{U} \cdot \mathrm{E}+\mathrm{n}_{1}$

Sasaran perolehan neto perikanan udang: $\mathrm{G}_{2}=$ h.U.E-c.E $+\mathrm{n}_{2}$

Sasaran keuntungan pelaku usaha:

$\mathrm{G}_{3}=(\mathrm{h} . \mathrm{U}-\mathrm{c})+\mathrm{n}_{3}$

Sasaran peluang kerja di kapal:

$\mathrm{G}_{4}=\mathrm{k} . \mathrm{E}+\mathrm{n}_{4}$

Kelimpahan stok udang:

$\mathrm{B}_{\mathrm{MSY}} \leq \mathrm{b}_{1}-\mathrm{b}_{2} . \mathrm{E}$

Produktivitas kapal perikanan udang:

$\mathrm{U}=\mathrm{a}_{1}-\mathrm{a}_{2} \mathrm{E}$ di mana:

$$
\begin{aligned}
\mathrm{w}_{1}, \mathrm{~W}_{2}, \mathrm{w}_{3}, \text { dan } \mathrm{w}_{4}= & \text { bobot yang } \\
& \text { mencerminkan } \\
& \text { prioritas masing- } \\
& \text { masing tujuan } \\
& \text { pengelolaan } \\
\mathrm{G}_{1}, \mathrm{G}_{2}, \mathrm{G}_{3}, \text { dan } \mathrm{G}_{4}= & \text { nilai sasaran ideal } \\
& \text { masing-masing } \\
& \text { tujuan pengelolaan } \\
= & \text { nilai sasaran } \\
& \text { minimal, sasaran } \\
& \text { tidakideal, masing- } \\
& \text { masing tujuan } \\
& \text { pengelolaan } \\
= & \text { nilai deviasi } \\
& \text { negatif dari } \\
& \text { tingkat kompromi } \\
& \text { masing-masing } \\
& \text { sasaran terhadap } \\
& \text { nilai idealnya } \\
= & \text { kelimpahan stok } \\
& \text { (biomassa) udang } \\
& \text { yang menghasilkan } \\
& m \text { a } x \text { i } m \text { m } m \\
\mathrm{n}_{1}, \mathrm{n}_{2}, \mathrm{n}_{3}, \text { dan } \mathrm{n}_{4} & \text { sustainableyield }
\end{aligned}
$$

Nilai masing-masing parameter/koefisien dan sasaran yang digunakan untuk pemrograman matematika dengan sasaran beragam tersebut disajikan pada Tabel 1 . Nilai dari h, c, dan k adalah berdasarkan atas data atau informasi tahun 2005, bersumber dari perusahaan anggota HPPI. Nilai dari $a_{1}, a_{2}, b_{1}, b_{2}$, dan $B_{\text {MSY }}$ bersumber dari Purwanto (2010), sedangkan nilai sasaran bersumber dari Purwanto (2011). Analisis dalam optimisasi dilakukan dengan non linear multiple goal programming menggunakan piranti lunak General Algebraic Modelling System (Brooke et al., 1992). Program General Algebraic Modelling System untuk optimisasi tersebut disajikan pada Lampiran 1. 
Nilai koefisien/parameter dan sasaran yang digunakan dalam pemrograman dengan sasaran beragam untuk pengelolaan perikanan udang di Laut Arafura

Table 1. The value of coefficients/parameters and goals used in a programming with multiple goals for the management of shrimp fishery in the Arafura Sea

\begin{tabular}{|c|c|c|c|}
\hline $\begin{array}{l}\text { Parameter/koefisien/sasaran/ } \\
\text { Coefficients/parameters/goals }\end{array}$ & $\begin{array}{l}\text { Nilail } \\
\text { Values }\end{array}$ & Satuan/Units & Keterangan/Remarks \\
\hline $\mathrm{G}_{1}$ & 45.851 & 1.000 ton/tahun $(1,000$ tonnes/year) & Nilai maximum sustainable yield/Quantity of maximum sustainable yield \\
\hline $\mathrm{L}_{1}$ & 40.551 & 1.000 ton/tahun $(1,000$ tonnes/year $)$ & Nilai maximum economic yield/Quantity of maximum economic yield \\
\hline $\mathrm{G}_{2}$ & 119.759 & US\$ juta/tahun (US\$ million/year) & Tingkat optimum keuntungan perikanan/The optimal profit of fishery \\
\hline $\mathrm{L}_{2}$ & 87.977 & US\$ juta/tahun (US\$ million/year) & $\begin{array}{l}\text { Keuntungan perikanan saat dicapai maximum sustainable yield/Profit } \\
\text { of fishery at maximum sustainable yield }\end{array}$ \\
\hline $\mathrm{G}_{3}$ & 294,8 & $\begin{array}{l}\text { US } \$ 1.000 / \mathrm{kapal} / \text { tahun } \\
\text { (US\$1,000/vessel/year) }\end{array}$ & $\begin{array}{l}\text { Keuntungan per kapal saat dicapai maximum economic yield/Profit per } \\
\text { vessel when maximum economic yield achieved }\end{array}$ \\
\hline $\mathrm{L}_{3}$ & 142,9 & $\begin{array}{l}\text { US\$ } 1.000 / \text { kapal/tahun } \\
\text { (US } \$ 1,000 / \text { vessel/year) }\end{array}$ & $\begin{array}{l}\text { Keuntungan per kapal saat dicapai maximum sustainable yield/Profit } \\
\text { per vessel when maximum sustainable yield achieved }\end{array}$ \\
\hline $\mathrm{G}_{4}$ & 12.936 & orang (people) & $\begin{array}{l}\text { Peluang kerja sebagai awak kapal penangkap udang saat dicapai } \\
\text { maximum sustainable yield/Opportunity for job as fishing vessel crews } \\
\text { when maximum sustainable yield achieved }\end{array}$ \\
\hline $\mathrm{L}_{4}$ & 8.526 & orang (people) & $\begin{array}{l}\text { Peluang kerja sebagai awak kapal penangkap udang saat dicapai } \\
\text { maximum sustainable yield/Opportunity for job as fishing vessel crews } \\
\text { when maximum sustainable yield achieved }\end{array}$ \\
\hline $\mathrm{h}$ & 5.996 & US $\$ 1.000 /$ ton (US $\$ 1,000 /$ tonnes) & \\
\hline c & 303.703 & $\begin{array}{l}\text { US } \$ 1.000 / \text { kapal/tahun } \\
\text { (US\$1,000/vessellyear) }\end{array}$ & \\
\hline $\mathrm{k}$ & 21 & orang/kapal (people/vessel) & \\
\hline$B_{M S Y}$ & 53.876 & 1.000 ton $(1,000$ tonnes $)$ & \\
\hline$a_{1}$ & 148.970 & & \\
\hline$a_{2}$ & 0,121 & & \\
\hline$b_{1}$ & 107.752 .485 & & \\
\hline $\mathrm{b}_{2}$ & 87.521 & & \\
\hline
\end{tabular}




\section{APLIKASI MODEL OPTIMISASI}

\section{Sasaran Beragam dengan Bobot Prioritas Sama}

Optimisasi menggunakan model matematika yang telah dijelaskan sebelumnya menghasilkan nilai estimasi kompromi optimal terhadap beragam sasaran yang saling bertentangan pada perikanan udang di Laut Arafura sebagaimana disajikan pada Tabel 2. Skenario pada optimisasi tersebut adalah untuk pengelolaan perikanan dalam kerangka Pembangunan Nasional, sehingga empat tujuan pengelolaan memiliki bobot prioritas yang sama.

Kompromi optimal tingkat produksi dan total keuntungan perikanan udang masingmasing adalah sekitar 45.000 ton/tahun dan US\$ 112 juta/tahun (Tabel2), dengan deviasi relatif terhadap masing-masing sasaran idealnya sekitar $25 \%$. Kompromi optimal tersebut mendekati sasaran ideal. Sementara itu, kompromi optimal tingkat keuntungan yang diperoleh pelaku usaha dan peluang kerja di kapal sekitar US\$ $219.000 / \mathrm{kapal} /$ tahun dan 10.731 orang. Deviasi relatif dua kriteria ini terhadap masing-masing sasaran idealnya sekitar $50 \%$. Kompromi optimal ini berada di tengah di antara batas atas yang merupakan sasaran ideal dan batas bawah yang merupakan sasaran tidak ideal. Kompromi optimal dari sasaran-sasaran ideal pengelolaan perikanan dicapai dengan pengendalian upaya penangkapan udang pada tingkat yang setara dengan daya tangkap dari 511 kapal pukat udang ukuran 130 GT (Tabel 2). Pada tingkat upaya penangkapan tersebut kelimpahan stok udang di Laut Arafura sekitar 63.000 ton. Biomassa udang pada kondisi dicapainya kompromi optimal dari sasaran beragam yang saling bertentangan tersebut lebih besar dibandingkan biomassa untuk mempertahankan kelestarian stok udang dengan laju pertumbuhan maksimum $\left(B_{\text {MSY }}\right)$.

Pemrograman optimisasi dengan beragam sasaran yang saling bertentangan dengan menggunakan titik acuan batas MSY, $E_{M S Y}, M E Y$, dan $E_{M E Y}$, sebagaimana disajikan dalam tulisan ini, menghasilkan $E_{M E Y}<E^{*}<E_{M S Y}$, yaitu tingkat upaya penangkapan optimal $\left(E^{*}\right)$ lebih rendah dibandingkan $E_{M S Y}$ namun lebih tinggi dibandingkan $\mathrm{E}_{\mathrm{MEY}}$. Deviasi relatif $\mathrm{E}^{*}$ terhadap $\mathrm{E}_{\mathrm{MSY}}$ dan $\mathrm{E}_{\mathrm{MEY}}$ sekitar $50 \%$. Dengan menggunakan acuan tingkat upaya penangkapan optimal hasil optimisasi tersebut dalam pengendalian penangkapan udang, pengelolaan perikanan selain menghasilkan capaian sasaran pada tingkat kompromi optimal juga lebih menjamin kelestarian stok udang. Pengendalian upaya penangkapan udang pada tingkat kompromi optimal mengkondisikan pemanfaatan sumber daya ikan pada tingkat optimal dan lestari. Hal ini juga akan mengkondisikan adanya iklim investasi yang lebih kondusif bagi kegiatan perikanan berbasis sumber daya alam hayati.

Tujuan-tujuan pengelolaan perikanan mencakup aspek ekonomi, sosial, sumber daya alam, dan lingkungan. Pemrograman optimisasi dengan beragam sasaran yang saling bertentangan, sebagaimana disajikan di sini, telah digunakan untuk mengestimasikan tingkat kesetimbangan di antara aspek-aspek tersebut. Deviasi relatif dari tingkat kompromi optimal terhadap sasaran ideal produksi dan total keuntungan perikanan udang (25\%) serta terhadap sasaran ideal keuntungan pelaku usaha dan peluang kerja di kapal $(50 \%)$ mengindikasikan kesetimbangan optimal di antara aspek-aspek tersebut. 

sasaran ideal yang diharapkan dan sasaran optimal yang merupakan kompromi dari beragam tujuan pengelolaan yang saling bertentangan pada perikanan udang di Laut Arafura

Table 2. Estimated impact of fishery management using maximum sustainable yield and maximum economic yield as reference points, and expected value of ideal goals and the optimal compromise solution for the four conflicting objectives of the management of Arafura Sea shrimp fishery

\begin{tabular}{|c|c|c|c|c|c|c|}
\hline & \multirow[b]{2}{*}{ Kriteria/Criteria } & \multirow[b]{2}{*}{ Satuan/Units } & \multicolumn{2}{|c|}{$\begin{array}{l}\text { Dampak kebijakan pengelolaan } \\
\text { perikanan/Estimated impact of } \\
\text { fishery management }\end{array}$} & \multirow{2}{*}{$\begin{array}{l}\text { Nilai sasaran ideal } \\
\text { pengelolaan } \\
\text { perikanan/ } \\
\text { Expected value of } \\
\text { ideal goals for } \\
\text { fishery } \\
\text { management }\end{array}$} & \multirow{2}{*}{$\begin{array}{l}\text { Kompromi } \\
\text { optimal/ } \\
\text { The optimal } \\
\text { compromise } \\
\text { solution }\end{array}$} \\
\hline & & & $\begin{array}{l}\text { MSY sebagai } \\
\text { acuan/ } \\
\text { MSY as a } \\
\text { reference point }\end{array}$ & $\begin{array}{c}\text { MEY sebagai } \\
\text { acuan/ } \\
M E Y \text { as a } \\
\text { reference point }\end{array}$ & & \\
\hline \multirow{2}{*}{ Pro-growth } & 1. Produksi udang/Shrimp production & ton/tahun (Tonnes/year) & 45.851 & 40.551 & 45.851 & 44.522 \\
\hline & $\begin{array}{l}\text { 2. Keuntungan perikanan } \\
\text { keseluruhan/Total fishery profit }\end{array}$ & $\begin{array}{l}\text { US\$ juta/tahun } \\
\text { (US\$ million/year) }\end{array}$ & 88 & 120 & 120 & 112 \\
\hline Pro-job & $\begin{array}{l}\text { 4. Peluang kerja di kapal/Job } \\
\text { opportunity as vessel crews }\end{array}$ & orang (people) & 12.936 & 8.526 & 12.936 & 10.731 \\
\hline Pro-environment & 5. Biomassa udang/Shrimp biomass & ton (tonnes) & 53.876 & 77.970 & $53.876^{\star 1}$ & 63.051 \\
\hline \multicolumn{2}{|c|}{ Upaya penangkapan/Fishing effort } & $\begin{array}{l}\text { Kapal pukat udang 130GT } \\
\text { (130 GT shrimp trawler) }\end{array}$ & 616 & 406 & & 511 \\
\hline \multirow{2}{*}{\multicolumn{2}{|c|}{$\begin{array}{l}\text { Produktivitas kapal pukat udang/Shrimp trawler } \\
\text { productivity } \\
\text { Perolehan perikanan keseluruhan/Total revenue of fishery }\end{array}$}} & $\begin{array}{l}\text { ton/kapal/tahun } \\
\text { (tonnes/vessel/year) }\end{array}$ & 74 & 100 & & 87 \\
\hline & & $\begin{array}{l}\text { US\$ juta/tahun } \\
\text { (US\$ million/year) }\end{array}$ & 275 & 243 & & 267 \\
\hline
\end{tabular}

Keterangan/Remarks: *) batas kelimpahan minimum/minimum abundance limit 


\section{Sasaran Beragam dengan Bobot Prioritas Berbeda}

Optimisasi lanjutan dilakukan dengan memberikan bobot prioritas yang berbeda terhadap masing-masing tujuan pengelolaan perikanan udang. Pada tulisan ini disajikan tiga alternatif skenario pengelolaan dengan pembobotan prioritas tujuan pengelolaan dengan nilai yang berbeda, yaitu (i) pengelolaan untuk mengoptimalkan keuntungan ekonomi, (ii) pengelolaan untuk mengoptimalkan produksi lestari dan peluang kerja, serta (iii) pengelolaan untuk mengoptimalkan produksi lestari dan keuntungan ekonomi perikanan udang guna mencapai visi dan misi Kementerian Kelautan dan Perikanan. Hasil optimisasi dengan berbagai skenario tersebut disajikan pada Tabel 3.

Tabel 3. Upaya penangkapan optimal untuk mencapai tingkat kompromi optimal dari beragam tujuan pengelolaan perikanan udang di Laut Arafura dengan bobot prioritas yang berbeda untuk masing-masing tujuan

Table 3. Optimal fishing effort to achieve optimal compromise levels for the conflicting objectives of the management of shrimp fishery in the Arafura Sea by prioritising different objectives

\begin{tabular}{|c|c|c|c|c|}
\hline \multicolumn{4}{|c|}{$\begin{array}{l}\text { Bobot prioritas masing-masing tujuan pengelolaan perikanan/ } \\
\text { Weight of priority for each objective of fisheries management }\end{array}$} & \multirow[b]{2}{*}{$\begin{array}{c}\text { Upaya } \\
\text { penangkapan } \\
\text { optimal } \\
\text { (Jumlah kapal }^{*} \text { ) } \\
\text { The optimal } \\
\text { fishing effort } \\
\text { (Number of } \\
\text { vessels })\end{array}$} \\
\hline $\begin{array}{c}\text { Tujuan I/ } \\
\text { Objective I: } \\
\text { Optimisasi } \\
\text { produksi udang/ } \\
\text { Optimisation of } \\
\text { shrimp } \\
\text { production }\end{array}$ & $\begin{array}{c}\text { Tujuan II/ } \\
\text { Objective II: } \\
\text { Optimisasi } \\
\text { keuntungan } \\
\text { perikanan/ } \\
\text { Optimisation of } \\
\text { fishery profit }\end{array}$ & $\begin{array}{c}\text { Tujuan III/ } \\
\text { Objective III: } \\
\text { Peningkatan } \\
\text { keuntungan pelaku } \\
\text { usaha/ } \\
\text { Increasing profit } \\
\text { gained by each fisher }\end{array}$ & $\begin{array}{c}\text { Tujuan IV/ } \\
\text { Objective IV: } \\
\text { Peningkatan } \\
\text { peluang kerja di } \\
\text { kapal/Increasing } \\
\text { job opportunity } \\
\text { as vessel crews }\end{array}$ & \\
\hline 1 & 1 & 1 & 1 & 511 \\
\hline 1 & 10 & 10 & 1 & 406 \\
\hline 1 & 100 & 100 & 1 & 406 \\
\hline 1 & 1.000 & 1.000 & 1 & 406 \\
\hline 10 & 1 & 1 & 10 & 616 \\
\hline 100 & 1 & 1 & 100 & 616 \\
\hline 1.000 & 1 & 1 & 1.000 & 616 \\
\hline 10 & 10 & 1 & 1 & 511 \\
\hline 100 & 100 & 1 & 1 & 511 \\
\hline 1.000 & 1.000 & 1 & 1 & 511 \\
\hline 10 & 1 & 10 & 1 & 511 \\
\hline 100 & 1 & 100 & 1 & 511 \\
\hline 1.000 & 1 & 1.000 & 1 & 511 \\
\hline 1 & 10 & 1 & 10 & 511 \\
\hline 1 & 100 & 1 & 100 & 511 \\
\hline 1 & 1.000 & 1 & 1.000 & 511 \\
\hline
\end{tabular}

Optimisasi dengan pemberian bobot prioritas yang lebih tinggi terhadap tujuan II dan III, yaitu dalam rangka mengoptimalkan keuntungan ekonomi, menghasilkan tingkat kompromi optimal yang dicapai dengan mengendalikan upaya penangkapan pada tingkat yang setara dengan 406 kapal pukat udang berukuran $130 \mathrm{GT}$ (Tabel 3). Tingkat upaya penangkapan tersebut setara dengan tingkat $\mathrm{E}_{\mathrm{MEY}}$. Sementara itu optimisasi dengan pemberian bobot prioritas yang lebih tinggi terhadap tujuan I dan IV, yaitu dalam rangka mengoptimalkan produksi lestari dan peluang kerja, menghasilkan 
tingkat kompromi optimal yang dicapai dengan mengendalikan upaya penangkapan pada tingkat yang setara dengan 616 kapal pukat udang berukuran 130 GT. Tingkat upaya penangkapan tersebut setara dengan tingkat $\mathrm{E}_{\mathrm{MSY}}$.

Optimisasi dengan pemberian bobot prioritas yang lebih tinggi terhadap tujuan I dan II, dalam rangka merealisasikan visi dan misi Kementerian Kelautan dan Perikanan, menghasilkan tingkat kompromi optimal yang tidak berbeda dari hasil optimisasi yang menggunakan bobot prioritas yang sama untuk semua tujuan, dalam rangka mendukung pembangunan nasional. Hal tersebut disebabkan karena tujuan I bertentangan dengan tujuan II. Hasil yang sama diperoleh dari optimisasi dengan pemberian bobot prioritas yang lebih tinggi terhadap tujuan I dan III, ataupun tujuan II dan IV. Hal ini dikarenakan tujuan I dan IV bertentangan dengan tujuan II dan III. Sementara itu, tujuan I tidak bertentangan dengan tujuan IV. Hal yang sama, tujuan II tidak bertentangan dengan tujuan III.

Hasil optimisasi tersebut menunjukkan bahwa pelaksanaan pengelolaan perikanan dengan memberikan bobot prioritas yang lebih tinggi terhadap tujuan I dan II dalam rangka mencapai visi dan misi Kementerian Kelautan dan Perikanan membutuhkan strategi pengelolaan yang tidak berbeda dari strategi pengelolaan perikanan dalam kerangka Pembangunan Nasional yang dilaksanakan untuk mencapai empat tujuan dengan bobot prioritas yang sama. Tingkat kompromi optimal terhadap sasaran ideal dari tujuan yang saling bertentangan dalam pengelolaan perikanan udang dalam kerangka pembangunan nasional maupun dalam rangka merealisasikan visi dan misi Kementerian Kelautan dan Perikanan dicapai dengan mengendalikan upaya penangkapan udang pada tingkat yang setara dengan daya tangkap dari 511 kapal pukat udang ukuran $130 \mathrm{GT}$.

Pada tahun 2007, upaya penangkapan udang dari armada penangkapan yang memiliki Surat Izin Penangkapan Ikan yang berlaku untuk beroperasi di Laut Arafura sekitar 466 unit setara dengan daya tangkap kapal pukat udang berukuran 130 GT (Purwanto, 2010). Tingkat upaya penangkapan tersebut lebih rendah dibandingkan tingkat upaya penangkapan untuk mencapai tingkat kompromi optimal yaitu 511 unit (Tabel 2). Oleh karena itu, bila kebijakan pengelolaan perikanannya adalah untuk mencapai tingkat kompromi optimal, jumlah kapal perikanan tersebut memungkinkan ditingkatkan sekitar 45 unit setara kapal pukat udang berukuran 130 GT.

Namun, alokasi pengoperasian kapal penangkap udang di Laut Arafura yang diberikan kepada pelaku usaha melalui Surat Izin Usaha Perikanan sampai tahun 2007 terdiri atas 440 unit dengan alat pukat udang dan 1.112 unit dengan alat pukat ikan (Purwanto, 2010). Bila seluruh alokasi pengoperasian kapal penangkap di Laut Arafura yang diberikan kepada pelaku usaha tersebut direalisasikan, tingkat upaya penangkapan udang akan mencapai sekitar 718 unit setara dengan daya tangkap kapal pukat udang berukuran 130 GT (Purwanto, 2010). Realisasi seluruh alokasi tersebut akan berakibat tidak tercapainya tingkat kompromi optimal, dengan kelebihan alokasi 207 unit upaya penangkapan setara kapal pukat udang berukuran 130 GT. Tingkat upaya penangkapan tersebut bahkan melebihi $\mathrm{E}_{\mathrm{MSY}}$, sehingga realisasi seluruh alokasi tersebut akan berakibat terjadinya pemanfaatan berlebih terhadap stok udang yang meningkatkan ancaman terhadap kelestarian sumber daya alam tersebut. Untuk menghindari resiko pemanfaatan berlebih terhadap stok udang tersebut sekaligus untuk mencapai tingkat 
kompromi optimal terhadap sasaran ideal dari beragam tujuan pengelolaan perikanan udang, perlu dilakukan pengurangan alokasi jumlah kapal yang dapat direalisasikan pengoperasiannya, atau pengendalian pengoperasian armada perikanan agar upaya penangkapannya berada pada tingkat kompromi optimal.

Pengendalian upaya penangkapan udang dalam mencapai sasaran pengelolaan optimal tidak akan berhasil bila pada perikanan udang terdapat praktek penangkapan secara ilegal. Oleh karena itu, pengendalian perikanan perlu dibarengi dengan upaya minimisasi kegiatan perikanan ilegal, yang dapat dilakukan dengan pelaksanaan pengawasan dan penegakan hukum.

\section{KESIMPULAN}

1. Sasaran ideal dari empat tujuan yang saling bertentangan pada pengelolaan perikanan udang di LautArafura tidak dapat dicapai secara bersamaan. Tingkat kompromi optimal terhadap empat tujuan yang saling bertentangan dari pengelolaan perikanan dalam kerangka pembangunan nasional dicapai dengan pengendalian upaya penangkapan udang pada tingkat yang setara dengan daya tangkap dari 511 kapal pukat udang ukuran 130 GT.

2. Pengelolaan perikanan dengan prioritas yang lebih tinggi terhadap dua tujuan yang mendukung upaya pencapaian visi dan misi Kementerian Kelautan dan Perikanan membutuhkan strategi pengelolaan yang tidak berbeda dari strategi pengelolaan perikanan yang dilaksanakan dalam kerangka pembangunan nasional untuk mencapai empat tujuan dengan bobot prioritas yang sama.

\section{UCAPAN TERIMAKASIH}

Ucapan terimakasih kepada Profesor Riset Dr. Ir. Subhat Nurhakim, M.S. dan Ir. Duto Nugroho, M.Si. atas komentar, koreksi, dan saran untuk penyempurnaan draft dari tulisan ini. Namun demikian, kesalahan yang terdapat dalam tulisan ini tetap menjadi tanggung-jawab penulis sepenuhnya.

\section{DAFTAR PUSTAKA}

Bailey, C., A. Dwiponggo, \& F. Marahudin. 1987. Indonesian marine capture fisheries. ICLARM. Studies and Reviews 10. $196 \mathrm{pp}$.

Brooke, A., D. Kendrick, \& A. Meeraeus. 1992. GAMS: A User's Guide, Release 2.25. The Scientific Press. South San Francisco.

Badrudin, B. Sumiono, \& N. Wirdaningsih. 2002. Laju tangkap, hasil tangkapan maksimum (maximum sustainable yield), dan upaya optimum perikanan udang di Laut Arafura. Jurnal Penelitian Perikanan Indonesia. 8 (4): 23-29.

Drynan, R. G. \& F. Sandiford. 1985. Incorporating economic objectives in goal programming for fishery management. Marine Resource Economics. 2: 175195.

Departemen Kelautan dan Perikanan. 2007. Buku Statistik Kelautan dan Perikanan. Departemen Kelautan dan Perikanan. Jakarta.

Food and Agriculture Organization. 1997. Fisheries management. Food and Agriculture Organization Technical Guidelines for Responsible Fisheries. No. 4. Rome. Food and Agriculture Organization. 82 pp. 
Gordon, H. S. 1954. The economic theory of the common property resource: The Fishery. Journal of Political Economy. 62: 124-42.

Kjaersgaard, J. \& J. L. Andersen. 2003. Multi objective management in fisheries: The case of the Danish industrial fishery in the North Sea. Danish Research Institute of Food Economics. 90 pp.

Mardle, S., S. Pascoe, M. Tamiz, \& D. Jones. 2000. Resource allocation in the North Sea demersal fisheries: A goal programming approach. Annals of Operations Research. 94: 321-342.

Mace, P. M. 2001. A new role for maximum sustainable yield in single species and ecosystem approaches to fisheries stock assessment and management. Fish and Fisheries. 2: 2-32.

Naamin, N. 1984. Dinamika populasi udang jerbung (Penaeus merguiensis de Man) di perairan Arafura dan alternatif pengelolaannya. Disertasi Doktor. Fakultas Pasca Sarjana. Institut Pertanian Bogor. 281 pp.

Purwanto. 2003. Status and management of the Java Sea fisheries. 793-832. In G. Silvestre, L. Garces, I. Stobutzki, M. Ahmed, R. A. Valmonte-Santos, C. Luna, L. Lachica-Aliño, P. Munro, V. Christensen, \& D. Pauly (eds.). Assessment, Management, and Future Directions for Coastal Fisheries in Asian Countries. WorldFish Center Conference Proceeding 67. 1,120 pp.

Purwanto. 2010. The Biological Optimal Level of the Arafura Shrimp Fishery. (Unpublished).

Purwanto. 2011. A Compromise Solution to the Conflicting Objectives in the
Management of the Arafura Shrimp Fishery. (Unpublished).

Quinn II, T. J. \& J. S. Collie. 2005. Sustainability in single species population models. Phil. Trans. R. Soc. B. $360: 147-162$.

Romero, C. \& T. Rehman. 1989. Multiple Criteria Analysis for Agricultural Decisions. Elsevier Science Publishers. Amsterdam. 257 pp.

Schaefer, M. B. 1954. Some aspects of the dynamics of populations important to the management of commercial marine fisheries. Bulletin of the Inter American Tropical Tuna Commission. 1: 25-56.

Schaefer, M. B. 1957. Some considerations of population dynamics and economics in relation to the management of marine fisheries. Journal of the Fisheries Research Board of Canada. 14: 669-81.

Sandiford, F. 1986. An analysis of multiobjective decision making for the Scottish inshore fishery. Journal of Agricultural Economics. 37: 207-219.

Undang-Undang Dasar Negara Republik Indonesia Tahun 1945.

Undang-Undang Nomor 31 Tahun 2004 Tentang Perikanan.

Undang-Undang Nomor 17 Tahun 2007 Tentang Rencana Pembangunan Jangka Panjang Nasional Tahun 2005-2025.

Widodo, J., Purwanto, \& S. Nurhakim. 2001. Evaluasi Penangkapan Ikan di Perairan ZEEI Arafura: Pengkajian Sumber Daya Ikan Demersal. Direktorat Jenderal Perikanan. Departemen Kelautan dan Perikanan. Jakarta. 50 pp. 
Lampiran 1. Program General Algebraic Modelling System untuk optimisasi dengan sasaran beragam dalam pengelolaan perikanan udang di Laut Arafura

Appendix 1. General Algebraic Modelling System programs for the optimisation of the management of shrimp fishery in the Arafura Sea with multiple goals

\$Title MANAGEMENT OF THE ARAFURA SHRIMP FISHERY - GOAL ANALYSIS

\section{SCALARS}

PRICE Price of shrimps in US $\$ 1000$ per tonnes/ 5.996 /

COST Cost of fishing in US $\$ 1000$ per vessel per yr / 303.703 /

ALFAO A0 coefficient of Schaefer production model / 148.970 /

ALFA1 A1 coefficient of Schaefer production model / 0.121 /

BETA0 BO coefficient of Schaefer biomass model/ 107752.485 /

BETA1 B1 coefficient of Schaefer biomass model/ 87.521 /

BIOMMSY Shrimp biomass at MSY in tonnes / 53876.438 /

CREW Number of people working on a shrimp trawler / 21 /

*Weights attached to each of the objectives

W1 Weight of priority for goal-1:QTYMSY /1/

W2 Weight of priority for goal-2:RENTMEY / 1 /

W3 Weight of priority for goal-3:VPROFMSY / 1 /

W4 Weight of priority for goal-4:LABORMSY / 1 /

* Ideal solution or Goals:

\begin{tabular}{|c|c|c|}
\hline YMSY & maximum sustainable yield in tonnes & | 45851.365 | \\
\hline RENTMEY & Total profit at MEY in US\$ million & | 1.1976E+5 / \\
\hline VPROFMEY & Profit per unit vessel at MEY in US $\$ 1000$ & $294.768 /$ \\
\hline LABORMSY & \multirow[t]{2}{*}{ Total labor engaged in shrimp fishery at MSY } & / 12936 \\
\hline & & \\
\hline QTYMEY & maximum sustainable yield in tonnes & / 40550.905 / \\
\hline RENTMSY & Total profit at MSY in US\$ million & / 87976.639 / \\
\hline MSY & \multirow{2}{*}{$\begin{array}{l}\text { Profit per unit vessel at MSY in US } \$ 1000 \\
\text { Total labor engaged in shrim fisherv at }\end{array}$} & 14 \\
\hline Ev & & 8526 \\
\hline
\end{tabular}

VARIABLES

GOAL

POSITIVE VARIABLES

RDEVCATCH Relative deviation from goal-1

RDEVRENT Relative deviation from goal-2

RDEVPROF Relative deviation from goal-3

RDEVLAB Relative deviation from goal-4

n1 Negative deviation from goal-1 in tonnes per year

n2 Negative deviation from goal-2 in US\$ 1000 per year

n3 Negative deviation from goal-3 in US $\$ 1000$ per vessel per year

n4 Negative deviation from goal-4 in people

RENT Resource rent generated in US $\$ 1000$ per year 
TREVN Total annual return of catching shrimps in US $\$ 1000$ per year TCOST Total annual cost of catching shrimps in US $\$ 1000$ per year VPROF Profit per unit vessel in US $\$ 1000$ per year TCATCH Total catch of shrimp fishery in tonnes per year CPUE Catch per unit effort of shrimp fishery in tonnes per year TLABOR Total labor engaged in shrimp fishery EFFORT Effort standardised in the number of shrimp trawlers BIOMASS Abundance of shrimp stock in tonnes;

\section{EQUATIONS \\ OBJECTIVE \\ RELDEVIATION1 \\ RELDEVIATION2 \\ RELDEVIATION3 \\ RELDEVIATION4 \\ GOALPRODN \\ GOALRRENT \\ GOALVPROFIT \\ GOALTLABOR \\ RESOURCERENT \\ FISHINGREVENUE \\ FISHINGCOST \\ VESSELPROFIT \\ PRODUCTION \\ PRODUCTIVITY \\ TOTALLABOR \\ SHRSTOCKCONST \\ STOCKABUNDANCE;}

OBJECTIVE..

RELDEVIATION1.. RDEVCATCH =E=n1/(QTYMSY - QTYMEY);

RELDEVIATION2.. RDEVRENT =E=n2/(RENTMEY - RENTMSY);

RELDEVIATION3.. RDEVPROF $=\mathrm{E}=\mathrm{n} 3$ (VPROFMEY - VPROFMSY);

RELDEVIATION4.. RDEVLAB =E=n4/(LABORMSY - LABORMEY);

GOALPRODN.. QTYMSY $=\mathrm{E}=\mathrm{TCATCH}+\mathrm{n1}$;

GOALRRENT.. $\quad$ RENTMEY $=E=R E N T+n 2$;

GOALVPROFIT.. VPROFMEY $=E=V P R O F+n 3$;

GOALTLABOR.. $\quad$ LABORMSY $=E=T L A B O R+n 4$;

RESOURCERENT.. $\quad$ RENT $=E=$ TREVN - TCOST;

FISHINGREVENUE.. $\quad$ TREVN $=\mathrm{E}=\mathrm{PRICE}{ }^{\star T} T \mathrm{CATCH}$;

FISHINGCOST.. $\quad T$ TCOST $=\mathrm{E}=\mathrm{COST}^{\star}$ EFFORT;

VESSELPROFIT.. VPROF $=E=P R I C E{ }^{*} C P U E-C O S T$; 
Model Optimisasi dengan Sasaran

Perikanan Udang di Laut Arafura (Purwanto)

PRODUCTION.. TCATCH $=E=$ EFFORT ${ }^{*}$ CPUE;

PRODUCTIVITY.. CPUE =E=ALFAO - ALFA1*EFFORT;

TOTALLABOR.. TLABOR $=E=C R E W * E F F O R T ;$

SHRSTOCKCONST.. BIOMASS $=\mathrm{G}=$ BIOMMSY;

STOCKABUNDANCE.. $\quad$ BIOMASS $=E=B E T A 0-B E T A 1^{*} E F F O R T$;

MODEL POLICY /ALL/;

SOLVE POLICY MINIMISING GOAL USING NLP 